TETFLE TEACHER EDCCATON THROUGH FLEXIBLE LEARNING IN AFRICA

JOURNAL
Official publication of the Unit for Distance Education

Faculty of Education

University of Pretoria

Web address: https://upjournals.up.ac.za/index.php/tetfle

Email address: tetflemanager@up.ac.za

\title{
A Two-prong Approach for Enhancing Teaching and Learning for 21st Century skills Development in Oyo State, Nigeria
}

\author{
Samuel O Babalola \\ Department of Arts and Social Science Education, University of Ibadan, Nigeria
}

ISSN: 2788-6298

DOI: https://doi.org/10.35293/tetfle.v2i1.87

\begin{abstract}
Formal Education in the 21st Century is focused on the development of learners' skills and competencies essential to navigate the complexities and uncertainties of the age. Effective acquisition of these skills in the school is predicated on adequate provision of technological resources, adequate school infrastructure and continuous professional development of teachers for innovative instructional delivery. Therefore, this study was carried out to investigate the extent to which infrastructural provisions and continuous professional development of teachers in secondary schools in Nigeria support the development and acquisition of 21st Century teaching and learning skills. The study which adopted the impact of school infrastructure on learning by Barrett et al.as a conceptual framework, used descriptive survey design. Two self-constructed instruments were used to collect data from (20) selected secondary schools, (50) teachers and (200) students. Data were analysed using frequency count, percentage score, mean, and standard deviation. Findings showed that the schools visited lack infrastructural provisions, the teachers do not have the requisite skills and the students are not aware of any other means of learning different from the conventional styles offered by their teachers. Therefore, this study offered a two-prong approach of immediate provision of technological infrastructure for schools and the development of teachers' professional skills through focused training targeted at enhancing their technological instructional delivery skills.
\end{abstract}

Keywords: 21st Century, Teaching Skills, Learning Skills, 21st Century Classrooms, Teachers and Learners.

CONTACT: Samuel O. Babalola so.babalola@mail.ui.edu.ng https://orcid.org/0000-0002-4423-3936

(c) (3) This work is licensed under a Creative Commons Attribution 4.0 International License. 


\section{Introduction}

Technological advancement has changed the traditional narratives of every sector known to man. It has brought meaningful changes and alteration to the traditional organisation of every sector. Significantly, the education sector has witnessed tremendous revolution since the turn of the century in the areas of school enrolment, curricular provisions, school administration, teachinglearning processes and societal expectations of students' learning outcomes. Coping with current challenges requires certain skills and competencies which are expected to be fostered through formal Education. Makuma (2016) explained that surviving in the 21st Century requires a sound education which offers a wide perspective on issues of global awareness, environmental literacy, digital literacy, and civic competence.

Through acquisition of formal Education, individuals are expected to develop skills and capabilities to meaningfully contribute to the development of their societies. As explained by Tan, Choo, Kang and Liem (2017) formal Education should promote the acquisition of competencies in the areas of: creative thinking, creativity, collaboration, communication, socio-emotional and lifelong learning aptitudes, resilience, and positive self-concept. In the same vein, Makuma (2016) highlighted 21st Century competencies to include critical thinking, problem solving, digital literacy, communication skills, social and cultural skills. Each of these highlighted skills is essential in navigating the structural complexities of daily life.

\section{1st Century Teaching Skills}

Teaching in the 21st century has assumed a sophisticated dimension which is driven by technology. Boholano (2017) explained that if the process of teaching will stimulate the necessary skills development of leaners, teachers are expected to possess sound and up to date instructional delivery strategies to aid their professional practice. In the past, the use of technology and flipped, blended and flexible educational provision was associated to open and distance education instructional delivery as open and distance instructors were expected to have these skills. However, the professional demands of the age require all teachers to focus on real-world problems and processes, support child centred and inquiry-based learning approaches, engage collaborative learning strategies and focus on guiding learners on how they can learn ahead of what to learn to promote the development of 21 st Century skills in their classrooms (Pacific Policy Research Center, 2010).

Furthermore, Tsisana (2015) maintained that a 21st Century teacher should be able to offer personalised instruction by creating classroom environments where learners can make their own learning choices which produce intrinsic motivation. As such the 21st Century teacher needs to develop expertise in handling new technologies (hard and soft), collaborate with students in creating digital resources and projects, innovate and maintain a positive disposition to life-long learning. Charalambidis (2014) while explaining the 21st Century demands of teaching pointed

CONTACT: Samuel O. Babalola so.babalola@mail.ui.edu.ng https://orcid.org/0000-0002-4423-3936

(C) (9) This work is licensed under a Creative Commons Attribution 4.0 International License. 
out that teachers have to understand the creative use of ICT tools, utilise up-to-date teaching strategies, intuitive assessment methods and lead and teach by example in order to assist learners to develop proficiency in critical thinking, effective communicate, collaboration and creativity.

However, the Pacific Policy Research Center (2010) maintained that for meaningful transformation to occur there is need to provide teachers with strong support systems and opportunities for professional development. It is when professional development is in place that teachers will be able to acquire skills and competencies to teach for the development of 21st Century skills development. Bybee \& Starkweather (2006); May (2018) and Bicaj, \& Treska, T. 2014 explained that professional development of teachers must of a necessity focus on how to use technology to improve students' achievements and how to instruct using standard-based lesson infused with technology. This implies that professional development programmes for teachers should be intentional with the aim of reshaping their classroom practice to be 21st Century compliant. As suggested by Guskey (2002), the professional development of teachers is not expected to end in a workshop or symposium but that there should be a follow up to the classroom level where the practice of the teacher can be observed and required assistance can be provided in form of support or mentoring. This helps teachers to translate knowledge acquired through professional development into actual classroom practice. Guskey (2002) also corroborated the fact that teaching 21st Century skills is mandated on providing teachers with continuous professional development that is supportive and allows them to question, practice, and explore emerging technologies. Guskey states that before a teacher can effectively teach and encourage 21st Century learning, they must have the interest, motivation, and support to do so.

\section{1st Century Learning Skills}

Learning in the 21st Century has taken a paradigm shift from the past century which was dominated by 'talk and chalk' method of instruction otherwise referred to as the teacher-centred method. The Education of the past century is no longer sufficient for preparing learners in this century for the complex challenges of the global market. Darling-Hammond (2010) confirms that the skills needed for the 21st Century global economy cannot be learnt in traditional educational systems. There is need for higher order cognitive engagement in the areas of critical and analytical thinking, problem solving, effective communication, digital literacy and global citizenship, (Mbaka, 2014). The success of learners lies in their ability to connect, share and utilise information to solve complex problems, their capability to adapt and demonstrate innovative skills based on the demands of their environments, and the know-how to utilise the technological skills to expand the frontiers of knowledge.

Charalambidis (2014) maintains that the 21st Century skills do not have specific descriptions, but that they are aimed at communicating the fact that technology has brought about changes in the

CONTACT: Samuel O. Babalola so.babalola@mail.ui.edu.ng https://orcid.org/0000-0002-4423-3936

(C) $\$(0)$ This work is licensed under a Creative Commons Attribution 4.0 International License. 
way things are being done and that the skills used in the past are no longer sufficient to cope with the demands of work in the present time. A review of related literature on what constitutes the 21st Century learning skills shows that there is a uniform understanding about the 4Cs which are: Critical thinking and problem solving, Collaboration, Communication and Creativity. The 4Cs are the higher-order thinking, cognitive and social competencies considered as requirements for success in the future (Organisation of Economic Cooperation and Development, 2005). In the words of Grose (2014), the 4Cs enable 21st Century learners to think in innovative ways with the ability to ask meaningful and interrogating questions of 'why', 'what', and 'how' so as to find profound answers that could serve as solutions to their curiosity.

Similarly, Pacific Policy Research Center, (2010), Charalambidis (2014) and Tan, Choo, Kang and Liem (2017) amongst others have identified the followings as additional skills 21st Century learners need to include: digital and information literacy, innovation and lifelong learning skills, meta-cognition, teamwork, flexibility, adaptability, global awareness, learning to learn, personal and social responsibility, environmental awareness, financial literacy, leadership, social-cultural skills, self-direction, etc. These highlighted skills in the explanation of Grose (2014), cover the three important domains of learning which are: the cognitive, the intra-personal and the interpersonal. It has been argued that the 21 st Century skills are not new, that they are skills that have been from time immemorial, but the mastery of these skills by learners in this century and their ability to maximise technology-driven learning paradigms to develop their potentials and expertise is the great advantage of the 21 st Century learner and learning in this age.

\section{1st Century School and Classrooms}

The school plays a significant role in the life of a learner. The school in the 21st Century is expected to provide the learner with new skills that must support their development in the society together their readiness to take up the world of work. Never before has the social development and economic organisation placed such an enormous demand on the school. The future reality requires more of today's learners to have 21st Century compliant skills along with their qualifications to be able to cope with the demands of this century in handling uncertainties, taking risks, working independently and with others; create solutions and make positive contributions to their societies which have become culturally diverse. A 21st Century school has to respond to these demands by putting structures in place to ensure that the expectations of the society are met. Thus, the on-going discussion among scholars, researchers and developmental agencies about what should constitute the 21st Century learning environments in terms of infrastructural provisions, pedagogical approaches, technological application, classroom atmosphere, etc. 21st Century schools according to the Pacific Policy Research Center (2010) is that learning environment where support systems are provided to organise the condition where learners can learn best. It is such an environment where the learning needs of an individual are catered for and where support is provided for positive human interaction for effective learning. It is also an

CONTACT: Samuel O. Babalola so.babalola@mail.ui.edu.ng https://orcid.org/0000-0002-4423-3936

(C) (9) This work is licensed under a Creative Commons Attribution 4.0 International License. 
environment where physical spaces (school atmosphere and classrooms), course contents, learning materials, learning activities, technology infrastructure, community involvements, etc. support the acquisition of skills and competencies that the 21 st Century requires. For a school to be 21st Century compliant, the Pacific Policy Research Center (2010) states further that, such schools should:

a. Enhance the creation of learning practices, human support and physical environments that will aid teaching-learning of 21st Century skills.

b. Aid professional learning groups that will promote the collaboration of teachers to share experiences and infuse 21st Century relevant skills into their instructional delivery.

c. Promote real-world experiences among learners through the use of personalised instructions and constructivist approaches.

d. Provide equal access to learning materials, technologies, resources, etc.

e. Create classroom atmosphere (furniture, interior design, sitting arrangements) that allow for student collaboration, group work and individual learning.

f. Promote continuous learning through virtual and face-to-face interaction.

Black (2007) and Sack-min (2007) argue that the quality of the learning environment (where students learn) affects the quality of how students learn and the quality of how students learn will undoubtedly affect the quality of what they learn. Cornell (2002) submitted that 21st Century learning needs to take place in an environment that fosters deep interaction and a sense of community that promotes organised and informal type of learning. Saxena (2013) while listing the characteristics of a 21st Century classroom maintained that the focus of a 21st Century classroom should be to provide learning experiences for students in an environment that is similar to what they will enter as modern day workers, stimulate their higher order thinking skills through skilful utilisation of technology and computer devices. In the area of pedagogy, he maintained that teachers must engage learners through new teaching strategies and effective instructional methods aided with technology to stimulate learners to take control of their learning and become knowledge producers. Saxena (2013) listed the characteristics of a 21st Century classroom to include:

a. A student-centred classroom where students' interests, needs, abilities and learning styles take priority and learners play active role in their learning.

b. An organised learning environment that is well planned and organised with flexible sitting arrangement.

c. A furnished classroom with computer devices, interactive whiteboards, LCD screens, projector, and internet provisions for online research and engaging instruction. Using

CONTACT: Samuel O. Babalola so.babalola@mail.ui.edu.ng https://orcid.org/0000-0002-4423-3936

(C) $(9)$ This work is licensed under a Creative Commons Attribution 4.0 International License. 
these devices is effective in stimulating active participation and engagement of learners in meaningful learning.

d. An adaptive learning environment that gives freedom to learners to learn at their pace using specific software to enhance learning.

Furthermore, Goertz (2015) listing the characteristics of a 21st Century classroom highlighted the integration of technology, collaborative environment, hands-on learning, teacher as facilitator, transparent assessment amongst others as the characteristics of a 21 st Century classroom. Canez (2018) explaining the importance of technology in the 21st Century classroom submitted that through technology students can personalise their learning and that through technological programs and software students can use devices to create new things, collaborate, explore contents and widen their exposure and knowledge.

\section{Statement of the Problem}

Education in the 21st Century is geared towards the development of learners' competencies in the areas of critical thinking, problem solving, effective communication and collaboration skills, socio-emotional intelligence, global awareness, aptitude for lifelong learning amongst others. To achieve this, scholars have agreed that purposeful and continuous professional development of teachers enabling them to offer personalised instruction, develop expertise in handling digital resources and utilise relevant assessment techniques is vital. Furthermore, the provision of technological resources to cater for learners needs and stimulate their learning capabilities coupled with adequate infrastructural provision in the school are indispensable to effective teaching and learning for 21st Century skills development. Previous studies have focused on the lack of adequate provision of school infrastructures and professional development of teachers without examining their implications for 21st Century skills acquisition in teaching and learning in secondary schools. Therefore, this study was carried out to investigate the extent to which infrastructural provisions and continuous professional development of teachers in secondary schools in Nigeria supports the development and acquisition of 21st Century teaching and learning skills.

\section{Research Questions}

1. What are the existing infrastructural provisions in Nigerian secondary school classrooms that can aid teaching-learning for 21 st Century skills development?

2. Is there provision for teachers' continuous professional development?

3. To what extent do secondary school teachers demonstrate 21st Century teaching skills in their classrooms?

4. What is the profile of the 21 st Century learning skills of secondary school students in Nigeria?

CONTACT: Samuel O. Babalola so.babalola@mail.ui.edu.ng https://orcid.org/0000-0002-4423-3936

(C) (9) This work is licensed under a Creative Commons Attribution 4.0 International License. 


\section{Conceptual Framework}

In an elaborate study carried out in developed, developing and under-developed educational systems, Barrett, Treves, Shmis, Ambasz and Ustinova (2019), concluded that irrespective of the nature of educational systems, infrastructural provisions in schools directly impact school learning and directly affect students' learning outcomes. They maintained that the nature of school buildings and layouts of learning spaces (classrooms), technology-based content and devices, innovative learning classrooms, and highly skilled teaching personnel who are attuned to learners' characteristics contributes significantly to desirable outcomes in learning and education. In their submission, they revealed that Education does not and cannot happen in a vacuum, decent school infrastructure serves as motivation for meaningful teaching and learning. On the other hand, they submitted that when schools are dirty, ugly and are ill-equipped, students learn the diminished value that their schools place on them and their future. Asaaju (2012), summarised that availability of quality school infrastructure and adequacy of this infrastructure is one of the ways to guarantee quality output in any educational system.

By concluding on the importance of infrastructural provision in schools as a significant factor that directly impacts students learning outcomes, the submission of Barrett, Treves, Shmis, Ambasz and Ustinova (2019), is unique to this study in that it assists the researcher to explain amongst others, the pivotal role of human and non-human infrastructural schools provision as two most critical factors that are required in teaching and preparing secondary school students for the acquisition of 21st Century learning skills. It is also useful in explaining that irrespective of the region or nature of the educational system, the output of any educational system cannot be better than the quality of investment in infrastructural schools provision and continuous professional development of its teachers.

\section{Methodology}

The study adopted descriptive survey design. Simple random sampling technique was used to select twenty (20) public secondary schools in Ibadan metropolis, Oyo State, Nigeria. Ten (10) senior secondary school II (Penultimate year) students were randomly selected from each school, a total of 200 students participated in the study. This was after approval and permission had been given by the school authority. Fifty $(50)$ teachers that participated in the study were randomly selected from the twenty (20) schools. Teachers participated based on interest/willingness after they had been assured of confidentiality and that the purpose is strictly for research. Two selfconstructed Likert instruments on a four-point scale (Not at All $=1$, A Little Extent $=2$, Some Extent $=3$ and Great Extent $=4$ ) titled "Teachers' 21st Century Teaching Skill Questionnaire (T2CTSQ)" with reliability coefficient of .950 and "Students' 21st Century Learning Skill Questionnaire (S2CLSQ)" with reliability coefficient of .945 were used to collect data from the

CONTACT: Samuel O. Babalola so.babalola@mail.ui.edu.ng https://orcid.org/0000-0002-4423-3936

(C) (9) This work is licensed under a Creative Commons Attribution 4.0 International License. 
teachers and students. Explanation was given to the students to assist them in completing the questionnaire. The sections B of the two self-constructed instruments were used to collect data on infrastructural provisions in all the selected schools. Data collected were analysed using frequency count, percentage score, mean, (the weighted mean average of 2.50 being the mean value of the 4-point Likert scale was used as decision rule) and standard deviation. The statistical Package for the Social Sciences, version 21 was used to analyse the data.

\section{Results}

Research Question 1: What are the existing infrastructural provisions in Nigerian school classrooms that can aid teaching-learning for 21 st Century skills development? 
Table 1

21st Century Infrastructural Classroom Provisions in Nigerian Secondary Schools

\begin{tabular}{llll}
\hline S/N & $\begin{array}{l}\text { ITEMS } \\
\text { Which of the following are present in the } \\
\text { classrooms where you teach? }\end{array}$ & Available & $\begin{array}{l}\text { Not } \\
\text { Available }\end{array}$ \\
\hline 1 & White boards & $2(4 \%)$ & $47(96 \%)$ \\
2 & Interactive boards & $1(2 \%)$ & $47(96 \%)$ \\
3 & Functional computer systems & - & $50(100 \%)$ \\
4 & Computer software or applications for & - & $50(100 \%)$ \\
& teaching & & $50(100 \%)$ \\
5 & $\begin{array}{l}\text { Projectors, video players, smart screens, } \\
\text { etc. }\end{array}$ & - & $50(100 \%)$ \\
7 & $\begin{array}{l}\text { Internet provision/connectivity } \\
\text { Conducive learning environment (furniture, }\end{array}$ & $5(10 \%)$ & $45(90 \%)$ \\
& interior design, sitting arrangements in & & \\
& groups, classroom lighting, etc.) & $2(4 \%)$ & $48(96 \%)$ \\
\hline
\end{tabular}

CONTACT: Samuel O. Babalola so.babalola@mail.ui.edu.ng https://orcid.org/0000-0002-4423-3936 
Table 1 presents the results of 21st Century infrastructural classroom provisions in Nigerian schools. It shows that the classrooms lack minimum 21st Century infrastructural provisions such as electricity supply as many of the schools are not connected to electricity. All of the selected schools do not have computers, internet connectivity, projectors, video players, smart screens, interactive boards etc. However, the table shows that few of the respondents identified interactive boards, whiteboards and electricity supply as available in their schools.

Research Question 2: Is there provision for teachers' continuous professional development?

Table 2

Teachers' Continuous Professional Development

\begin{tabular}{|c|c|c|c|}
\hline $\mathbf{S} / \mathbf{N}$ & $\begin{array}{l}\text { When was the last time you participated in the } \\
\text { following? }\end{array}$ & Yes & No \\
\hline 1 & $\begin{array}{l}\text { Workshops/seminars on the creative use of ICT for } \\
\text { effective instructional delivery }\end{array}$ & - & $\begin{array}{l}44 \\
(100 \%)\end{array}$ \\
\hline 2 & $\begin{array}{l}\text { A workshop/seminar for teachers on innovative } \\
\text { instructional or teaching strategies }\end{array}$ & - & $\begin{array}{l}49 \\
(100 \%)\end{array}$ \\
\hline 3 & $\begin{array}{l}\text { A seminar/training on } 21 \text { st Century teaching skills } \\
\text { and assessment techniques }\end{array}$ & - & $\begin{array}{l}49 \\
(100 \%)\end{array}$ \\
\hline 4 & $\begin{array}{l}\text { Professional development programme sponsored by } \\
\text { your employer }\end{array}$ & $\begin{array}{l}6 \\
(12.5 \%)\end{array}$ & $\begin{array}{l}42 \\
87.5 \%)\end{array}$ \\
\hline
\end{tabular}

CONTACT: Samuel O. Babalola so.babalola@mail.ui.edu.ng https://orcid.org/0000-0002-4423-3936 
Table 2 shows the provision for teachers' continuous professional development available to improve their teaching skills in line with 21st Century practices. It showed that Item 1, 2, and 3 were ranked negatively by $100 \%$ of the participants, respectively, while item 4 was positively ranked by $12 . \%$ of the participants and ranked negatively by $87.5 \%$. This implies that there was no adequate provision for continuous teachers' professional development in secondary schools.

Research Question 3: To what extent do school teachers in Nigeria demonstrate 21st Century teaching skills in their classrooms?

Table 3

Nigerian Teachers' Practice of 21st Century Teaching Skills in the Classroom

\begin{tabular}{|c|c|c|c|c|c|c|c|}
\hline$S / N$ & $\begin{array}{l}\text { ITEMS } \\
\text { To what extent do you do the } \\
\text { following while teaching in the } \\
\text { classroom: }\end{array}$ & $\begin{array}{l}\text { Not at } \\
\text { All } \\
\text { (F) }(\%)\end{array}$ & $\begin{array}{l}\text { A } \\
\text { Little } \\
\text { Extent } \\
\text { (F) (\%) }\end{array}$ & $\begin{array}{l}\text { Some } \\
\text { Extent } \\
\text { (F) }(\%)\end{array}$ & $\begin{array}{l}\text { Great } \\
\text { Exten } \\
\mathbf{t} \\
\text { (F) } \\
(\%)\end{array}$ & MEAN & STD. \\
\hline 1 & $\begin{array}{l}\text { Offer personalized instruction(s) to } \\
\text { students }\end{array}$ & $\begin{array}{l}34 \\
(70.8 \%)\end{array}$ & $\begin{array}{l}14 \\
29.2 \%\end{array}$ & - & - & 1.29 & .459 \\
\hline 2 & $\begin{array}{l}\text { Utilise child-centred strategies in } \\
\text { teaching. }\end{array}$ & $\begin{array}{l}31 \\
(64.6 \%)\end{array}$ & $\begin{array}{l}11 \\
(22.9 \\
\%)\end{array}$ & $\begin{array}{l}6 \\
(12.5 \%)\end{array}$ & - & 1.48 & .714 \\
\hline 3 & $\begin{array}{l}\text { Allow students to provide solutions } \\
\text { to real-world problems. }\end{array}$ & $\begin{array}{l}23 \\
(47.9 \%)\end{array}$ & $\begin{array}{l}17 \\
(35.4 \\
\%)\end{array}$ & $\begin{array}{l}8 \\
(16.7 \%)\end{array}$ & - & 1.69 & .748 \\
\hline 4 & $\begin{array}{l}\text { Teach students by creatively } \\
\text { engaging technological devices. }\end{array}$ & $\begin{array}{l}36 \\
(85.7 \%)\end{array}$ & $\begin{array}{l}6 \\
(14.3 \\
\%)\end{array}$ & & - & 1.14 & .354 \\
\hline 5 & $\begin{array}{l}\text { Allow students to work together or in } \\
\text { groups. }\end{array}$ & $\begin{array}{l}13 \\
(28.9 \%)\end{array}$ & $\begin{array}{l}19 \\
(42.2 \\
\%)\end{array}$ & $\begin{array}{l}13 \\
(28.9 \%)\end{array}$ & - & 2.00 & .769 \\
\hline 6 & $\begin{array}{l}\text { Practice classroom-based } \\
\text { assessment for learning. }\end{array}$ & $\begin{array}{l}33 \\
(67.3)\end{array}$ & $\begin{array}{l}16 \\
(32.7)\end{array}$ & - & - & 1.33 & .474 \\
\hline 7 & $\begin{array}{l}\text { Provide students with real-world } \\
\text { experiences. }\end{array}$ & $\begin{array}{l}24 \\
(48.0 \%)\end{array}$ & $\begin{array}{l}16 \\
(32.0 \\
\%)\end{array}$ & $\begin{array}{l}10 \\
(20.0 \%)\end{array}$ & - & 1.72 & .784 \\
\hline 8 & $\begin{array}{l}\text { Play relevant videos to illustrate a } \\
\text { lesson to students. }\end{array}$ & $\begin{array}{l}34 \\
(70.8 \%)\end{array}$ & $\begin{array}{l}14 \\
(29.2 \\
\%)\end{array}$ & - & - & 1.29 & .459 \\
\hline 9 & $\begin{array}{l}\text { Take students out to important } \\
\text { places relevant to building real-world } \\
\text { experiences. }\end{array}$ & $\begin{array}{l}41 \\
(87.2 \%)\end{array}$ & $\begin{array}{l}6 \\
(12.8 \\
\%) \\
\end{array}$ & - & - & 1.13 & .337 \\
\hline
\end{tabular}

CONTACT: Samuel O. Babalola so.babalola@mail.ui.edu.ng https://orcid.org/0000-0002-4423-3936

(c) (9) This work is licensed under a Creative Commons Attribution 4.0 International License. 


\begin{tabular}{|c|c|c|c|c|c|c|c|}
\hline $\mathbf{S / N}$ & $\begin{array}{l}\text { ITEMS } \\
\text { To what extent do you do the } \\
\text { following while teaching in the } \\
\text { classroom: }\end{array}$ & $\begin{array}{l}\text { Not at } \\
\text { All } \\
\text { (F) }(\%)\end{array}$ & $\begin{array}{l}\text { A } \\
\text { Little } \\
\text { Extent } \\
\text { (F) (\%) }\end{array}$ & $\begin{array}{l}\text { Some } \\
\text { Extent } \\
\text { (F) }(\%)\end{array}$ & $\begin{array}{l}\text { Great } \\
\text { Exten } \\
\text { t } \\
\text { (F) } \\
(\%)\end{array}$ & MEAN & $\overline{\text { STD. }}$ \\
\hline 10 & $\begin{array}{l}\text { Allow students to use the Internet to } \\
\text { carry out research on a topic of } \\
\text { interest. }\end{array}$ & $\begin{array}{l}38 \\
(88.4 \%)\end{array}$ & $\begin{array}{l}3 \\
(7.0 \%)\end{array}$ & $\begin{array}{l}2 \\
(4.7 \%)\end{array}$ & - & 1.16 & .485 \\
\hline 11 & $\begin{array}{l}\text { Collaborate with students to provide } \\
\text { a solution to an identified problem in } \\
\text { your school or community. }\end{array}$ & $\begin{array}{l}31 \\
(66.0 \%)\end{array}$ & $\begin{array}{l}13 \\
(27.7 \\
\%)\end{array}$ & $\begin{array}{l}3 \\
(6.4 \%)\end{array}$ & & 1.40 & .614 \\
\hline 12 & $\begin{array}{l}\text { Collaborate with other teachers to } \\
\text { improve your pedagogical skills. }\end{array}$ & $\begin{array}{l}22 \\
(45.8 \%)\end{array}$ & $\begin{array}{l}16 \\
(33.3 \\
\%)\end{array}$ & $\begin{array}{l}10 \\
(20.8 \%)\end{array}$ & & 1.75 & .786 \\
\hline
\end{tabular}

Key: Not at All $=1, \quad$ A Little Extent $=2$, Some Extent $=3$ and Great Extent $=4$

Weighted Mean $=1.47$

Table 3 presents Nigerian teachers' demonstration of 21st Century teaching skills in the classroom. Even though fifty (50) teachers participated in the study, some items were left unchecked by the respondents. This explains why many of the items have frequency values that are less than fifty (50). Table 3 shows that

- $\quad$ item 1 was ranked positively by $29.2 \%$ of the respondents, while $70.8 \%$ ranked negatively.

- Item 2 was ranked positively by $29.2 \%$ of the respondents, while $64.6 \%$ ranked negatively.

- Item 3 was ranked positively by $16.7 \%$ of the respondents, while $83.3 \%$ ranked negatively.

- Item 4 was ranked negatively by $100 \%$ of the respondents.

- Item 5 was ranked positively by $28.9 \%$ of the respondents, while $71.1 \%$ ranked negatively.

- Item 6 was ranked negatively by $100 \%$ of the respondents.

- Item 7 was ranked positively by $20 \%$ of the respondents, while $80 \%$ ranked negatively.

- Item 8 and 9 was ranked negatively by $100 \%$ of the respondents, while

- item 10 was ranked positively by $4.7 \%$ of the respondents and negatively by $95.7 \%$.

- Item 11 and 12 were ranked positively by $6.4 \%$ and $20.8 \%$ of the respondents, while $94.6 \%$ and $79.2 \%$ ranked negatively.

Therefore, the extent of teachers' demonstration of 21st Century teaching skills in their classrooms is critically low as shown by the weighted mean (1.47) which is far below the established criterion norm of 2.5. The Statistical Package for the Social Science (SPSS) version 21 was used to obtain the frequency and the mean values.

Research Question 4: What is the profile of the 21st Century learning skills of secondary school students in Nigeria?

CONTACT: Samuel O. Babalola so.babalola@mail.ui.edu.ng https://orcid.org/0000-0002-4423-3936 
Volume 2, 2020

Table 4

Profile of 21st Century Learning Skills of Students in Secondary Schools in Nigeria

\begin{tabular}{|c|c|c|c|c|c|c|c|}
\hline $\mathbf{S} / \mathbf{N}$ & $\begin{array}{l}\text { ITEMS } \\
\text { Do you manifest these skills in } \\
\text { learning important concepts in } \\
\text { and out of the classroom? }\end{array}$ & $\begin{array}{l}\text { Not at } \\
\text { All } \\
\text { F (\%) }\end{array}$ & $\begin{array}{l}\text { A Little } \\
\text { F (\%) }\end{array}$ & $\begin{array}{l}\begin{array}{l}\text { Someti } \\
\text { mes }\end{array} \\
\text { F (\%) }\end{array}$ & $\begin{array}{l}\text { Alwa } \\
\text { ys } \\
\text { F (\%) }\end{array}$ & Mean & STD. \\
\hline 1 & $\begin{array}{l}\text { Discover/stumble on new facts as a } \\
\text { result of deep thinking about a } \\
\text { specific problem? }\end{array}$ & $\begin{array}{l}121 \\
(64.4 \%)\end{array}$ & $\begin{array}{l}38 \\
(20.2 \%)\end{array}$ & $\begin{array}{l}29 \\
(15.4 \%)\end{array}$ & - & 1.51 & .749 \\
\hline 2 & $\begin{array}{l}\text { Engage in critical thinking together } \\
\text { with your classmates to provide } \\
\text { answers to difficult problems given to } \\
\text { you as group work or project? }\end{array}$ & $\begin{array}{l}136 \\
(74.4 \% \\
\&\end{array}$ & $\begin{array}{l}26 \\
(14.3 \%)\end{array}$ & $\begin{array}{l}16 \\
(8.8 \%)\end{array}$ & $\begin{array}{l}4 \\
(2.2 \% \\
)\end{array}$ & 1.38 & .740 \\
\hline 3 & $\begin{array}{l}\text { Collaborate with your teachers and } \\
\text { students to solve identified problems } \\
\text { in your school or community? }\end{array}$ & $\begin{array}{l}127 \\
(67.9 \%)\end{array}$ & $\begin{array}{l}26 \\
(13.9 \%)\end{array}$ & $\begin{array}{l}24 \\
(12.8 \%)\end{array}$ & $\begin{array}{l}10 \\
(5.3 \% \\
)\end{array}$ & 1.56 & .910 \\
\hline 4 & $\begin{array}{l}\text { Participate in classroom activities by } \\
\text { asking questions from your } \\
\text { teachers? }\end{array}$ & $\begin{array}{l}93 \\
(50.3 \%)\end{array}$ & $\begin{array}{l}23 \\
(12.4 \%)\end{array}$ & $\begin{array}{l}37 \\
(20.0 \%)\end{array}$ & $\begin{array}{l}31 \\
(16.8 \\
\%)\end{array}$ & 2.14 & $\begin{array}{l}1.88 \\
0\end{array}$ \\
\hline 5 & $\begin{array}{l}\text { Have you ever been taught by your } \\
\text { teachers with computers, phones, } \\
\text { videos, etc.? }\end{array}$ & $\begin{array}{l}148 \\
(74.7 \%)\end{array}$ & $\begin{array}{l}28 \\
(14.1 \%)\end{array}$ & $\begin{array}{l}17 \\
(8.6 \%)\end{array}$ & $\begin{array}{l}5 \\
(2.5 \%\end{array}$ & 1.39 & .751 \\
\hline 6 & $\begin{array}{l}\text { Can you relate well with students } \\
\text { who are not from your ethnic or } \\
\text { religious group? }\end{array}$ & $\begin{array}{l}31 \\
(15.5 \%)\end{array}$ & - & $\begin{array}{l}63 \\
(31.5 \%)\end{array}$ & $\begin{array}{l}106 \\
(53.0 \\
\%)\end{array}$ & 3.38 & .740 \\
\hline 7 & $\begin{array}{l}\text { Utilise devices such as computers, } \\
\text { phones, tablets etc. to complete your } \\
\text { class activities or assignments? }\end{array}$ & $\begin{array}{l}162 \\
(83.5 \%)\end{array}$ & $\begin{array}{l}13 \\
(6.7 \%)\end{array}$ & $\begin{array}{l}12 \\
(6.2 \%)\end{array}$ & $\begin{array}{l}7 \\
(3.6 \%\end{array}$ & 1.30 & .743 \\
\hline 8 & $\begin{array}{l}\text { Solve problems relating to your } \\
\text { schoolwork through searching the } \\
\text { Internet for solutions or answers? }\end{array}$ & $\begin{array}{l}174 \\
(95.6 \%)\end{array}$ & $\begin{array}{l}7 \\
(3.8 \%)\end{array}$ & $1(.5 \%)$ & - & 1.05 & .241 \\
\hline 9 & $\begin{array}{l}\text { Participate in Internet or online } \\
\text { learning activities with your } \\
\text { classmates or people who are in } \\
\text { separate locations? }\end{array}$ & $\begin{array}{l}143 \\
(79.0 \%)\end{array}$ & $\begin{array}{l}20 \\
(11.0 \%)\end{array}$ & $\begin{array}{l}10 \\
(5.5 \%)\end{array}$ & $\begin{array}{l}8 \\
(4.4 \% \\
)\end{array}$ & 1.35 & .779 \\
\hline 10 & $\begin{array}{l}\text { Can speak with confidence among } \\
\text { your peers in the class without } \\
\text { feeling afraid? }\end{array}$ & $\begin{array}{l}78 \\
(39.2 \%)\end{array}$ & $\begin{array}{l}42 \\
(21.1 \%)\end{array}$ & $\begin{array}{l}46 \\
(23.1 \%)\end{array}$ & $\begin{array}{l}33 \\
(16.6 \\
\%)\end{array}$ & 2.17 & $\begin{array}{l}1.12 \\
4\end{array}$ \\
\hline
\end{tabular}

Key: Not at All $=1, \quad$ A Little Extent $=2$, Some Extent $=3$ and Great Extent $=4$

Weighted Mean $=1.72$

CONTACT: Samuel O. Babalola so.babalola@mail.ui.edu.ng https://orcid.org/0000-0002-4423-3936 
Table 4 presents the profile of 21st Century learning skills of students in Nigeria. Even though two hundred students were selected to participate in the study, some of these students did not respond to some items in the questionnaire. This is the reason why many of the items on the table have frequency values less than two hundred 200 . The table shows that

- item 1 was ranked positively by $15.4 \%$ of the participants, while $84.6 \%$ ranked negatively.

- Item 2 was ranked positively by $11 \%$ of the participants, while $89 \%$ ranked negatively.

- Item 3 was ranked positively by $18.1 \%$ of the participants, while 81.9 ranked negatively.

- Item 4 was ranked positively by $36.8 \%$ of the participants, while $62.7 \%$ ranked negatively.

- Item 5 was ranked positively by $11.1 \%$ of the participants, while $88.8 \%$ ranked negatively.

- Item 6 was positively ranked by $84.5 \%$ of the participants, while 15.5 ranked negatively.

- Item 7 was ranked positively by $9.8 \%$ of the participants, while $90.2 \%$ ranked negatively.

- Item 8 was ranked positively by $.5 \%$ of the participants, while 99.5 ranked negatively.

- Item 9 was ranked positively by $9.9 \%$ of the participants, while $90 \%$ ranked negatively.

- Item 10 was ranked positively by $39.7 \%$ of the participants, while $40.3 \%$ ranked negatively. Therefore, the 21st Century learning skills of students are critically low and inadequate as shown by the weighted mean (1.72), which is far below the established criterion norm of 2.5 .

\section{Discussion of Findings}

\section{Infrastructural Provisions in Secondary Schools Classrooms and 21st Century Skills Development in Oyo State, Nigeria}

Findings from the data analysed show that public secondary school classrooms in Ibadan, Oyo State, Nigeria lacks 21st Century infrastructural provisions. In its present condition, the standard of the public secondary school classrooms in Ibadan, Oyo State, falls short of what is expected in the 21st Century. The poor state of infrastructural provisions in secondary schools in different parts of Nigeria have been decried in separate studies carried out by Oladunni, Oladipo and AyoVaughan (2014); Amadi and Ohaka (2018); Asaaju, (2012) and Ojeje and Adodo, (2018). In most states in Nigeria, public secondary school classrooms lack basic infrastructural provisions in an era when developed nations like the United Kingdom and others are investing heavily in projects aimed at exploring the nature of future classrooms and exemplar designs for schools. This why Mbaka (2014), established that investing in 21st Century infrastructural provisions for Education is not optional since it is at the forefront of driving knowledge economy, reducing digital divide among countries and growing the economy. Quite significantly, the submissions of Barrett, Treves, Shmis, Ambasz and Ustinova (2019), which formed the conceptual framework of this study corroborates that decent school infrastructure serve as motivation for meaningful teaching and learning. No educational system can fully realise its educational potential without heavy investment in infrastructural provisions in schools and by extension the classroom. By implication, if Oyo State intends to prepare students with 21 st Century skills for the global economy which is

CONTACT: Samuel O. Babalola so.babalola@mail.ui.edu.ng https://orcid.org/0000-0002-4423-3936

(c) (9) This work is licensed under a Creative Commons Attribution 4.0 International License. 
driven largely by human capital development, technology and the Internet, there must be a radical attempt to change the current state of infrastructural provisions in schools. As observed by Canez (2018) and Barrett et al. (2019), irrespective of the region or nature of the educational system, when there is 21st Century infrastructural provision which is central to 21st Century skills acquisition in the classroom, students are able to interact, collaborate and provide solutions to a wide range of problems. It gives them a sense of independence to learn at their pace and also affords them the ability to explore, analyse, create and communicate facts from their personal or collective projects.

\section{Nigerian Teachers' Continuous Professional Development and Demonstration of 21st Century Teaching Skills}

Findings from the data analysed show that the 21st Century teaching skills of teachers is very poor. These results really cannot be separated from the poor continuous professional training of teachers and the dearth of 21st Century infrastructural provisions currently witnessed in many secondary schools in Nigeria. Barett et al. (2019), attributed highly skilled teaching personnel to positive students learning outcomes. They argued that effective learning outcomes does not and cannot happen in a vacuum and insisted that only skilled personnel equipped with decent school infrastructure can facilitate gainful teaching and learning. It is practically difficult for teachers to develop 21st Century teaching competencies when they are not exposed to innovative and personalised teaching strategies through workshops, seminars and specialised training sessions. It is disturbing that many of these teachers have not gone through any form of professional development in line with 21st Century teaching strategies and assessment techniques. Several scholars have established that students may not be able to acquire 21st Century competencies without teachers who have been trained specifically to provide instructions that will support the acquisition of these skills. Such training is expected to cover curriculum modelling, digital instruction, up-to-date instructional strategies, relevant classroom-based assessment techniques, and creative use of ICT. (Pacific Policy Research Center, 2010; Charalambidis, 2014; and Tsisana 2015).

\section{1st Century Learning Skills of Students in Schools in Nigeria}

The findings show that the profile of 21 st Century learning skills of students is critically low. Many of the students do not have learning skills in areas critical to 21st Century learning such as critical thinking, technological applications, etc. In this study, what is attributed to teachers' lack of 21st Century teaching skills cannot be separated from students' lack of 21st Century learning skills since these skills and competencies cannot be acquired in isolation. For students to acquire 21st Century skills, they must be guided and imparted by a teacher who has acquired these skills. As explained by Pacific Policy Research Center (2010), Charalambidis (2014) and Tan, Choo, Kang and Liem (2017) technological skills, information literacy, metacognition, etc. are essential skills

CONTACT: Samuel O. Babalola so.babalola@mail.ui.edu.ng https://orcid.org/0000-0002-4423-3936

(C) $(9)$ This work is licensed under a Creative Commons Attribution 4.0 International License. 
that 21 st Century learners should possess to contribute effectively to the society and stay competitive in the future.

\section{Summary and Recommendation}

The results of this study have established a relationship between adequate provision of school infrastructures, continuous professional development of teachers and the acquisition of 21st Century teaching and learning skills in secondary schools. It has shown that teachers in public secondary schools in Ibadan, Oyo State, Nigeria lack continuous professional development which is taking its toll on their inability to demonstrate 21 st Century teaching skills such as delivering personalised instruction amongst others. Furthermore, the study reported a dearth in the infrastructural/technological provision in the classrooms and this have been linked to the inability of students to acquire skills such as problem-solving, metacognition, collaboration and teamwork which are germane to 21st Century learning. It has been explained that with this trend of findings it will be difficult for Nigeria education system to prepare students with skills and competencies required to meaningfully participate in 21 st Century knowledge economy. Therefore, this study recommends that government (at all levels) and all stakeholders who are saddled with the responsibility of controlling secondary education sector, particularly the Oyo State Government of Nigeria, should as a matter of urgency accelerate the provision of technological and physical infrastructures for public secondary schools in Oyo State. This also applies to other state governments in Nigeria. It is also recommended that deliberate effort should be made to provide continuous professional skills development for teachers of public secondary schools, so they could be exposed to innovative and technological instructional strategies.

CONTACT: Samuel O. Babalola so.babalola@mail.ui.edu.ng https://orcid.org/0000-0002-4423-3936 


\section{References}

Amadi, N. S. \& Ohaka, A. O. 2018. Influence of poor infrastructure on vocational teacher education in Rivers State universities. International Journal of Innovative Social \& Science Education Research. Vol. 6:1, 54-62. www.seahipaj.org

Asaaju, O. A. 2012. Reconstruction of infrastructure for quality assurance in Nigeria Public Secondary Schools. Procedia - Socialand Behavioural Sciences 69. 924 - 932. www.sciencedirect.com

Barrett, P., Treves, A., Shmis, T., Ambasz, D., \& Ustinova, M. 2019. The impact of school infrastructure on learning: a synthesis of the evidence. World Bank Group. DOI: 10.1596/978-14648-1378-8

Bicaj, A. \& Treska, T. 2014. The effect of teacher professional development in raising the quality of teaching. Academic Journal of Interdisciplinary Studies. Vol. 3:(6)

Boholano H. B. 2017. Smart social networking: $21^{\text {st }}$ Century teaching and learning skills. Research in Pedagogy, Vol. 7:1, 21-29.

Bybee, R. W., \& Starkweather, K. N. 2006. The twenty-first Century workforce: A contemporary challenge for technology education. The Technology Teacher (May/June 2006), 27-32.

Canez, D. 2018. 21st Century learning practices: A case study of student response and motivation in the classroom. M. A. dissertation in Education. San Marcos: California State University.

Charalambidis, D. 2014. ICT in the future classrooms and teaching: preparing the knowledge workers of the 21 st Century. International Federation for Information Processing Workshop. IFIP AICT 437, 56-62.

Darling-Hammond, L. 2010. The flat world and education: How America's commitment to equity will determine our future. New York, NY: Teachers College Press.

Goertz, P. 2015. 10 Signs of a 21st Century classroom. [online]. Available at: https://www.edutopia.org/discussion/10-signs-21st-century-classroom. Accessed:15 July, 2019.

Grose, K. 2014. From 21st Century learning to learning in the 21stCentury: influences on transforming teacher knowledge of constructivist practices in technology-rich learning environments. Ph.D dissertation. Onatrio: University of Toronto.

May, B. P. 2018. Teachers' professional development in school: a review study. Cogent Education. 5:1. https://doi.org/10.1080/2331186X.2018.1522781

CONTACT: Samuel O. Babalola so.babalola@mail.ui.edu.ng https://orcid.org/0000-0002-4423-3936 
Mbaka, N. K. 2014. Technology in enhancing 21st Century learning skills in public secondary schools in Kenya. Available at https://pdfs.semanticscholar.org/e43b/7e758f2b8f8eb1b0fb1c7c615ce8743d7f8a.pdf Accessed 20 July 2016.

Ojeje, M. A. \& Adodo, A. 2018. Education infrastructure in Nigeria: an analysis of provision of school building facility in secondary schools in Delta State Nigeria. Journal of Education and Entrepreneurship. Vol. 5: 3, 49 - 60. https://doi.org/10.26762/jee.2018.400021

Oladunni, I. M., Oladipo, D. A. \& Ayo-Vaughan, K. 2014. Infrastructure conditions in public secondary schools, Ogun State Nigeria. International Journal of Civil, Structural, Environmental and Infrastructure Engineering Research and Development. Vol. 4:5, 17-24. www.tjprc.org

Organisation for Economic Cooperation and Development, 2005. The definition and selection of key competencies: executive summary. Paris, France: OECD.

Pacific Policy Research Center. 2010. 21st Century skills for students and teachers. Honolulu: Kamehameha Schools, Research \& Evaluation Division.

Sack-Min, J. 2007. Building the perfect school. American School Board Journal, October 2007.

Saxena, S. 2013. Top 10 characteristics of a 21st Century classroom. Available at https://edtechreview.in/news/862-top-10-characteristics-of-a-21st-century-classroom Accessed 15 July 2019.

Tan, J. P. Choo, S. S. Kang, T. \& Liem, G. A. 2017. Educating for twenty-first Century competencies and future-ready learners: research perspectives from Singapore, Asia Pacific Journal of Education, 37:4, 425-436.

Tsisana Palmer, 2015. 15 Characteristics of a 21st-Century teacher. Available at https://www.edutopia.org/discussion Accessed 6 July 2019.

Ultralab, building the learning futures 21st Century schools, learning environments of the future. Available at www.buildingfutures.org.uk Accessed 6 July 2019

CONTACT: Samuel O. Babalola so.babalola@mail.ui.edu.ng https://orcid.org/0000-0002-4423-3936 